\title{
Management of Covid-19 Vaccination for the Elderly
}

\author{
Deitje Adolfien Katuuk ${ }^{\mathbf{1}}$, Jeffry Sony Junus Lengkong ${ }^{2}$, Viktory Nicodemus Joufree \\ Rotty $^{3}$, Rinny Meilani Tinangon ${ }^{4}$ \\ ${ }_{1,2,3,4}$ Doctorate Program in Management of Education, Universitas Negeri Manado, Indonesia \\ deitjekatuuk@unima.ac.id, jeffrylengkong@unima.ac.id,viktoryrotty@unima.ac.id, \\ tinangon.rinny@yahoo.co.id
}

\begin{abstract}
Report of covid-19 Center for Disease Control (CDC) in16 March showed that $31 \%$ of the 4,226 confirmed COVID-19 cases were people aged $\geq 65$ years. The susceptibility of elderly individuals to several diseases is due to decreased immunity. Therefore, COVID19 vaccination is an important step to take. This article aims to determine the management of COVID-19 vaccination in the elderly. Based on the results of the analysis, it can be concluded that vaccination is a preventive strategy to increase immunity in the elderly. Although the immune response is greatly reduced due to the aging process, the right adjuvant formulation can increase the effectiveness of the vaccine. An understanding of the adjuvant mechanism to increase vaccine effectiveness is needed to develop a stronger vaccine response in elderly individuals.
\end{abstract}

Keywords vaccination management, covid-19, elderly

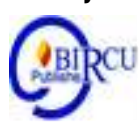

\section{Introduction}

The Covid-19 pandemic caused everyone to behave beyond normal limits as usual (Sihombing and Nasib, 2020). The reconsideration and evaluation of the wars of hegemony with Covid 19 pass through the redefinition of the world that has entered the global crisis (Güçyetmez et al., 2020). Since the outbreak of the corona virus that was recorded starting at the end of 2019 in China, precisely the city of Wuhan, then later this virus became global and infected almost all countries in the world including Indonesia. The world health agency (WHO) has also announced that the corona virus, also called COVID19 , is a global threat worldwide (Ningrum et al., 2020).

Since the first report, cases of respiratory tract infections caused by a new type of virus called Severe Acute Respiratory Syndrome Coronavirus 2 (SARS-CoV2) at the end of 2019, with the disease called Corona Virus Disease 2019 (COVID-19) have infected more than 2 (two) million people in less than 5 (five) months around the world.

The report of CDC COVID-19 in 16 March showed that $31 \%$ of the 4,226 confirmed cases of Covid-19 were people aged $\geq 65$ years. $45 \%$ of 508 patients who are hospitalized are elderly (Team et al., 2020). The severity of Indonesia's COVID-19 cases at the end of August was still greater than the global figure, namely 4.3\% (Azwar et al., 2020).

The Task Force for the Acceleration of Handling COVID-19 found that the death cases were higher than the cured cases in the elderly 70 years and over. The age group $\geq 60$ years had the lowest cure rate for COVID-19 (9.4\%) and the highest mortality rate (41\%) compared to all age groups (COVID, 2020). As many as 53\% of COVID-19 patients admitted to the ICU are elderly patients with the highest percentage of severe symptoms in the age group $\geq 85$ years. In contrast, in the age group $\leq 19$ years, there was no history of patients requiring ICU care or cases of patients dying (Team et al., 2020). The prognosis of COVID-19 in elderly patients is worse than in younger patients, most of the COVID-19 
patients who require hospitalization are the elderly or patients with concomitant chronic disease (T.Li et al., 2020). Decrease in the immune system and specific immunoregulation are the main causes of death cases of COVID-19 in the elderly (Azwar et al., 2020). Therefore, COVID-19 vaccination is an important step to take.

This article discusses the management of COVID-19 vaccination in the elderly. The demand for health care will clearly increase as a result of this demographic revolution. Successful vaccination of important infectious pathogens in the elderly is a major prevention strategy that must be emphasized now and in the future.

\section{Review of Literature}

\subsection{Vaccination Management}

The success of the vaccine has been proven if you see that there have been 3 diseases that have been eradicated in the world, namely smallpox which was declared wiped out by WHO in 1978, polio (only a few sufferers are left in Pakistan and Afghanistan, most countries in the world have no cases in humans), and rinderpest on cows (Greenwood, 2014). The immense role of vaccines becomes more real when the disease above does not have any effective cure. The three diseases above have no definitive cure.

The role of prevention becomes even more significant in this respect for other vaccine infectious diseases, showing a remarkable degree, at least when comparing the number of cases in the pre-vaccine era with the current situation. (Schuchat, 2011) Although Jenner's actions constituted some ethical and scientific aspects, they proved successful and the development of vaccines then became more prevalent. Until 2020, there are only about 40 vaccines for humans in the world. Seventeen vaccines in service, infections for viral infections (Kaslow, 2020). Of the seventeen, specifically for viral respiration, only 1 vaccine is available, namely for influenza (Giurgea et al., 2020). The current influenza vaccine has limited effectiveness against seasonal influenza and will not be able to cope with pandemic influenza (Morens \& Taubenberger, 2019).

\subsection{COVID-19}

The COVID-19 pandemic is the third case that humanity has faced with the coronavirus. The first case experienced in 2002-2003 was dealing with the Severe Acute Respiratory Syndrome Corona-virus (SARS-CoV) virus which also occurred in China and Hong Kong. The second case of the corona virus has even occurred to this day. Middle East Respiratory Syndrome-Coronavirus (MERS-CoV) disease appeared in Saudi Arabia and has not been resolved until now (of the International, 2020); (Tay et al., 2020).

Severe Acute Respiratory Syndrome Corona-virus-2 have genetic sequences similar to SARS-CoV and MERSCoV as much as $79 \%$ and 50\%. Several proteins in SARS-CoV2 have $68 \%$ similarities in amino acid composition with the SARS-CoV virus (Prompetchara et al., 2020); (Lu et al., 2020). The killing ability of SARS-CoV-2 is less dangerous than SARS-CoV, but the ability to infect other people is higher in SARS-CoV2. (Q. Li et al., 2020). The fact that the two SARS-CoV uses the ACE2 receptor and has the same genetic sequence at some level is the basis why researchers used the SARS-CoV vaccine prototype for SARS-CoV2 (Zhou et al., 2020); (Hoffmann et al., 2020)

\subsection{Elderly}

Elderly is the final stage in human life. Humans who enter this stage are marked by a decrease in the ability of the body as a result of the change or decrease function of body organs. According to WHO, the elderly are divided into three groups: 


\section{a. elderly : age between $60-75$ years \\ b. old : age between 76-90 years \\ c. very old : age between $>90$ years}

The health of the elderly is affected by the aging process. The aging process is defined as changes that are time-related, universal, intrinsic, progressive, and detrimental. This situation causes the ability to adapt to the environment and the ability to survive is reduced. The aging process of each individual and every organ of the body is different, this is influenced by lifestyle, environment, and degenerative diseases. The process of aging and physiological changes in the elderly lead to several setbacks and weaknesses, as well as clinical implications in the form of chronic disease and infection.

\section{Results and Discussion}

Vaccination aims to keep the immune system against infectious agents. Vaccines contain the same antigenic substances as foreign pathogens so that the immune system can recognize foreign pathogens and produce $\mathrm{T}$ cells and $\mathrm{B}$ cells. Vaccination is a strategy to enhance the immune system of elderly individuals in order to reduce morbidity and mortality associated with infection (Dey et al., 2012). The vaccination campaign in the elderly has reduced $25 \%$ morbidity, $50 \%$ pneumopathy, $20 \%$ hospital admissions, and $70 \%$ mortality (Ongrádi \& Kövesdi, 2010).

Influenza and pneumonia are the fourth leading causes of death in individuals 65 years of age or older. The Center for Disease Control (CDC) recommends individuals over 50 years of age to get vaccinated for pneumococcal pneumonia and influenza. The influenza vaccine should be given to elderly people every year before flu season arrives. This vaccine reduces by approximately $30 \%$ the chance of hospital admission for vascular disease (myocardial infarction or stroke) and pneumonia associated with influenza. The pneumococcal vaccine has a protective effectiveness of up to $60-70 \%$ against invasive pneumococcal infection. Polyvalent single dose injection should be given to individuals aged 65 years who have not received previous immunizations. The second dose is recommended to given for 5 years after the first dose at 19-64 years of age with asplenia and decreased immunity due to haematological malignancies, renal failure, or long-term corticosteroid therapy. The Herpes Zooster vaccine is also recommended to be given to the elderly to reduce the incidence of herpes infections and complications, especially neuralgia after herpes infection. The Food Drug Association (FDA) recommends that a single dose of Zostavax be used at age 60 or older to prevent neuritis regardless of whether they have been infected with chickenpox or not. This vaccine reduces the incidence of nerve inflammation by $51.3 \%$ and post-herpes neuralgia by $66.5 \%$ (Dey et al., 2012).

The challenge of administering vaccines to the elderly is due to the influence of the aging process in facilitating the antibody response after vaccination (Fagundes et al., 2012). Elderly individuals show a lower response to influenza vaccines, as evidenced in studies showing that elderly individuals have lower titer antibody than the controls (Kiecolt-Glaser et al., 2003). Decreased TNF- $\alpha$ and increased IL-10 production were associated with a lower antibody response to influenza vaccination. IL-10 works by inhibiting the maturation of Antigen Presenting Cell (APC) and inducing anergy of CD4 T cells. The genotype of the immune system appears to be increased in elderly individuals to be associated with a protective effect against neurodegenerative diseases (Corsini et al., 2006). Another study examining the response of the peumococcal pneumonia vaccine in elderly individuals showed that although 2-4 weeks after vaccination, the antibody titers were the same as the controls, but after 3-6 months later the antibody titers of the elderly 
individuals decreased markedly when compared to the control (Glaser et al. al., 2000). Meanwhile, the tetanus, diphtheria, pertussis and hepatitis $\mathrm{B}$ vaccines are unable to produce protective antibodies in individuals over the age of 60 (Chen et al., 2009). The design of vaccination for the elderly is important to increase the effectiveness of the vaccine.

Indonesia reported the first case of COVID-19 on March 2, 2020 and the number continues to grow until now. As of June 30, 2020, the Ministry of Health reported 56,385 confirmed COVID-19 cases with 2,875 deaths (CFR 5.1\%) spread across 34 provinces. As many as $51.5 \%$ of cases occurred in men. Most cases occur in the age range 45-54 years and the least occurs at the age of $0-5$ years. The highest mortality rate is found in patients aged 55-64 years (RI., 2020).

Based on research conducted by the Chinese CDC, it is known that the most cases occurred in men $(51.4 \%)$ and occurred at the age of 30-79 years and the least occurred at $<10$ years old $(1 \%)$. As many as $81 \%$ of cases were mild cases, $14 \%$ were severe, and $5 \%$ were critical (Wu \& McGoogan, 2020). People who are elderly or have congenital diseases are known to be more at risk for developing more severe disease. Old age is also thought to be associated with mortality rates. The Chinese CDC reports that the CFR of patients $\geq 80$ years of age is $14.8 \%$, while the overall CFR is only $2.3 \%$. The same was found in a study in Italy, where the CFR at age $\geq 80$ years was $20.2 \%$, while the overall CFR was $7.2 \%$ (Onder et al., 2020). The death rate is also influenced by the presence of congenital diseases in the patient. Rates of $10.5 \%$ were found in patients with cardiovascular disease, $7.3 \%$ in patients with diabetes, $6.3 \%$ in patients with chronic respiratory disease, $6 \%$ in patients with hypertension and $5.6 \%$ in patients with cancer.

Patients who are elderly and have comorbid diseases (for example: cardiovascular disease and diabetes) have a greater risk of experiencing more severe symptoms and experiencing death, so they can be considered for treatment. Rapid detection of COVID-19 is carried out according to clinical manifestations and according to the operational definition of COVID-19 surveillance. The treatment of elderly confirmed COVID-19 patients requires a multidisciplinary approach between doctors, nurses, pharmacists and other health professionals in the decision-making process given the multi-morbidity and functional decline issues of the body. Age-related physiological changes will decrease the patient's intrinsic function such as malnutrition, decreased cognitive function and symptoms of depression. Early detection of the possibility of improper drug administration should be carried out to avoid the occurrence of adverse events and drug interactions for elderly patients. Elderly people have a greater risk of experiencing polypharmacy, with the provision of new drugs related to COVID-19, coordination with caregivers or families is required during the COVID-19 management process to avoid negative impacts on patient health (RI., 2020). 


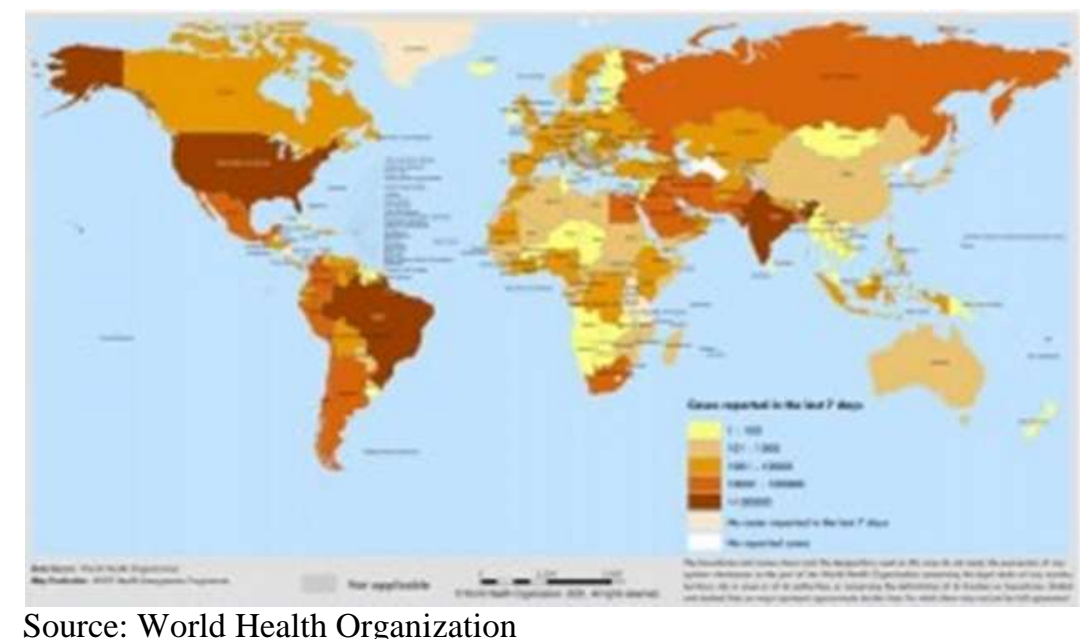

Figure 1. Map of the Distribution of COVID-19

Lot of work have been done to produce a vaccine for COVID-19. Such approaches include classic attenuated and attenuated vaccines ( 7 teams are working on this with two inactivated vaccines in clinical trials), protein and viral subunits such as particle vaccine (VLP) (28 teams on the vaccine subunit, mostly on the Spike protein and 5 in VLP), viral vector-based vaccines ( 25 teams with one in clinical trials), as well as newer DNA and RNA-based vaccines (20 teams with one of each type in clinical trials) (Callaway, 2020). Each approach has advantages and disadvantages and all approaches are being developed simultaneously to produce an effective vaccine in terms of (Amanat \& Krammer, 2020).

Among the virus' four structured proteins, the Spike protein is considered the most promising for vaccine development because: (1) it is common to the wide variety of coronaviruses that are found, and (2) indeed to an individual's immune system, enabling the body to make an immune response to and reminder for future protection. Furthermore, such a vaccine could prevent infection since it would inhibit the entry of the virus into susceptible cells. Due to previous experience with vaccine development for SARS in 2003 (against SARS-CoV), scientists have started using protein $S$ for vaccine development and some vaccines have entered clinical trials in humans, while others are currently in the trial phase (Mandate \& Krammer, 2020) (Shang et al., 2020).

In an effort to increase high and evenly distributed vaccination coverage through increasing access to quality and standard vaccination services, including in the context of implementing COVID-19 vaccination services, a comprehensive planning process is needed. The planning process for the implementation of vaccination is carried out by each administrative level. With good planning, vaccination service activities are expected to run well too. In carrying out the activity of providing COVID-19 vaccination, planning is prepared by taking into account basic data (number of health service facilities / vaccination service posts, implementing personnel, difficult areas, etc.). The components of the COVID-19 vaccination planning are described in the figure below: 


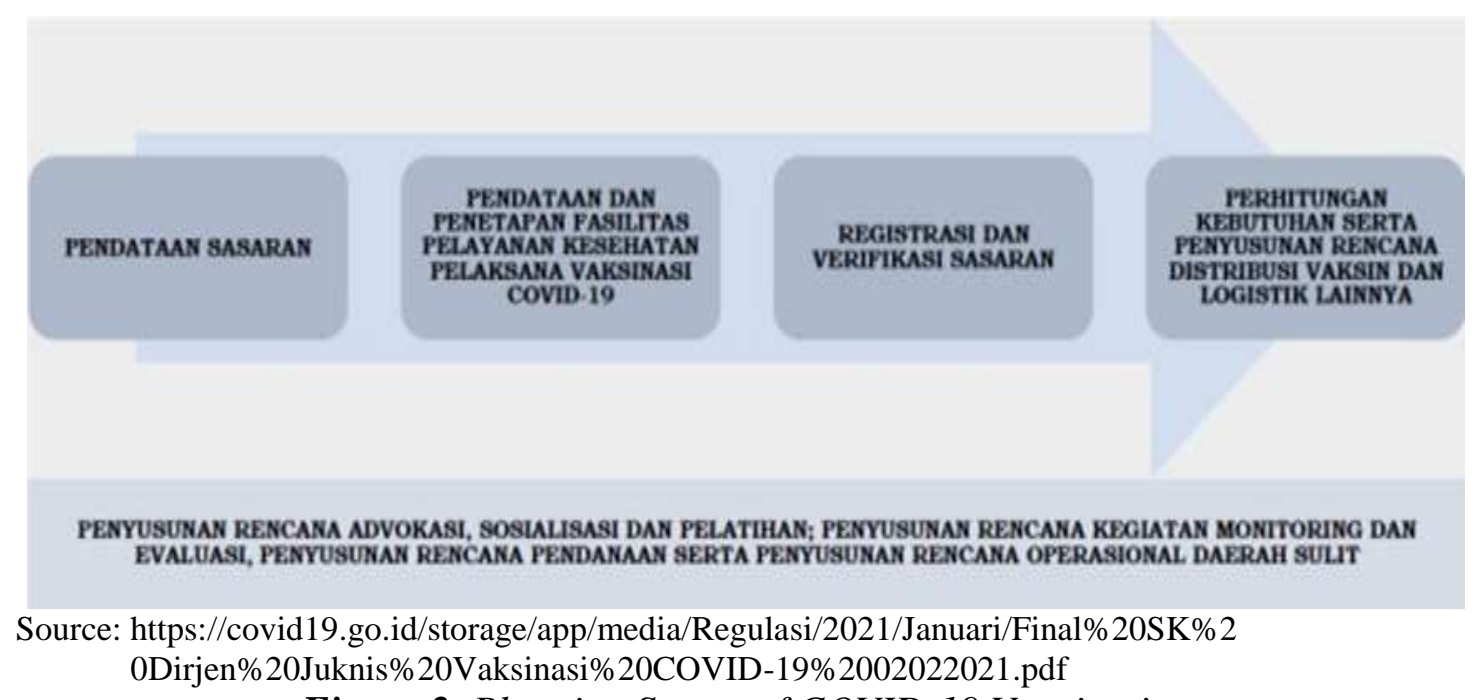

Figure 2. Planning Stages of COVID-19 Vaccination

Vaccination for COVID-19 is carried out in 4 stages considering the availability, time of arrival and safety profile of the vaccine. Priority group of vaccine recipients are residents who are domiciled in Indonesia who are $\geq 18$ years old. Population groups under 18 years of age can be vaccinated if there is adequate data on vaccine safety and emergency use authorization or the issuance of a distribution permit number (NIE) from the Food and Drug Supervisory Agency (BPOM). The vaccination stages with the implementation time from January to April 2021 are carried out in the elderly group ( $\geq 60$ years).

The staging and determination of priority groups for vaccine recipients is carried out by taking into account the road map of the WHO Strategic Advisory Group of Experts on Immunization (SAGE) as well as a review of the National Immunization Expert Advisory Committee (Indonesian Technical Advisory Group on Immunization).

According to the road map prepared by the WHO Strategic Advisory Group of Experts on Immunization (SAGE), because vaccine supplies will not be immediately available in sufficient quantities to vaccinate all targets, there are three scenarios for vaccine supply to be considered by countries, namely as follows:

1. Stage I when vaccine availability is very limited (ranging from $1-10 \%$ of the total population of each country) for initial distribution

2. Phase II when the supply of vaccines increases but availability remains limited (ranging from $11-20 \%$ of the total population of each country);

3. Stage III when the vaccine supply reaches moderate availability (ranging from $21-50 \%$ of the total population of each country).

The priorities to be vaccinated according to the WHO Strategic Advisory Group of Experts on Immunization (SAGE) road map are;

1. Health workers who are at high to very high risk for infection and transmitting SARSCoV-2 in the community.

2. Groups with a risk of death or serious disease (comorbid). The indication for administration is adjusted to the safety profile of each vaccine.

3. Social / occupational groups who are at high risk of contracting and transmitting the infection because they are unable to effectively distance themselves (public officials).

In the event that there is data on targets that have not received tickets or there are differences in the data and the number of targets reported and recapitulated, reconciliation is carried out by involving the relevant Ministries of Institutions. Determination of the number of targets per group of vaccine recipients at the Provincial and Regency / City 
levels become the basis for determining the allocation and distribution of vaccines and vaccination logistics by also considering reserves as needed.

Based on the COVID-19 Vaccination Service is carried out in Health Service Facilities owned by the Central Government, Provincial Government, Regency / City Government or owned by private communities that has the requirements. The District / City Health Office will collect data on health service facilities that will be the places for implementing COVID-19 vaccination services. Data collection is carried out through coordination efforts with all health service facilities including data collection on implementing personnel, service schedules and cold chain equipment available in every health service facility.

The principles in implementing the COVID-19 vaccination are: 1. Covid-19 vaccination is administered by a competent doctor, nurse or midwife, proven by the possession of a Registration Certificate (STR); 2. Implementation of the COVID-19 vaccination service does not interfere with routine immunization services and other health services; 3. Conducting screening-screening of target health status before vaccination is administered; 4. Implement health protocols; and 5. Integrate with COVID-19 surveillance activities, especially in case detection and impact analysis.

\subsection{Covid-19 Vaccination Service Standards}

Covid-19 vaccination services must apply health protocols, including room arrangement, service timing taking into account the maximum number of targets per session and the availability of personnel. Local governments can form a team to supervise the implementation of this COVID-19 vaccination service so that it continues to run in accordance with the service line mechanism both at clinic, health service facilities, and health protocols. other vaccinations as well as postal vaccination services can be seen in Figure 3.

\begin{tabular}{|c|c|c|c|}
\hline $\begin{array}{c}\text { Meja 1A } \\
\text { Pendaftaran } \\
\text { (Apabila } \\
\text { dibutuhkan, } \\
\text { dapat } \\
\text { disiapkan } \\
\text { Meja 1B yaitu } \\
\text { Meja Verifikasi } \\
\text { Data Sasaran) }\end{array}$ & $\begin{array}{c}\text { Meja } 2 \\
\text { (disarankan >1 } \\
\text { meja, sesuaikan } \\
\text { dengan jumlah } \\
\text { tenaga kesehatan } \\
\text { yang ada) } \\
\text { Skrining } \\
\text { Anamnesa dan } \\
\text { pemeriksaan fisik } \\
\text { sederhana } \\
\text { Edukasi } \\
\text { Vaksinasi } \\
\text { COVID-19 }\end{array}$ & $\begin{array}{c}\text { Meja } 3 \\
\text { (disarankan >1 } \\
\text { meja, sesuaikan } \\
\text { dengan jumlah } \\
\text { tenaga } \\
\text { kesehatan yang } \\
\text { ada, di dalam } \\
\text { ruangan dengan } \\
\text { tetap } \\
\text { menerapkan } \\
\text { protokol } \\
\text { kesehatan) } \\
\text { Pemberian } \\
\text { Vaksin }\end{array}$ & $\begin{array}{c}\text { Pencatatan dan } \\
\text { observasi } \\
\text { Petugas } \\
\text { mempersilakan } \\
\text { sasaran untuk } \\
\text { menunggu } 30 \\
\text { menit } \\
\text { (antisipasi } \\
\text { apabila ada } \\
\text { KIPI) } \\
\text { Sasaran } \\
\text { diberikan kartu } \\
\text { vaksinasi dan } \\
\text { penanda } \\
\text { Edukasi } \\
\text { pencegahan } \\
\text { COVID-19 }\end{array}$ \\
\hline
\end{tabular}

Source: (Indonesia, 2021)

Figure 3. COVID-19 vaccination service standards 
The implementation of the COVID-19 Vaccination has been carried out since January 13, 2021 and is carried out in stages with a target of 181.5 million people. Based on the letter of the Ministry of Health of the Republic of Indonesia, the Directorate General of Disease Prevention and Control number HK.02.02 / I / 368/2021 concerning the Implementation of COVID-19 Vaccination in the Target Group for the Elderly, Comorbid and Survivors of COVID-19 as well as the target of delay, in the second point it says that the implementation giving vaccination follows the technical instructions for the implementation of COVID-19 vaccination, including:

1. Elderly

Vaccination in the age group of 60 years and over was given 2 (two) doses with an interval of 28 days ( 0 and 28 ).

2. Comorbid Group

a. Hypertension can be vaccinated unless the blood pressure is above 180/110 $\mathrm{MmHg}$, and blood pressure measurements should be taken before the screening table.

b. Diabetes can be vaccinated as long as there are no acute complications

c. Cancer survivors can still be given vaccines

3. COVID-19 survivors can be vaccinated if they have been more than 3 months old

4. Breastfeeding mothers can be vaccinated

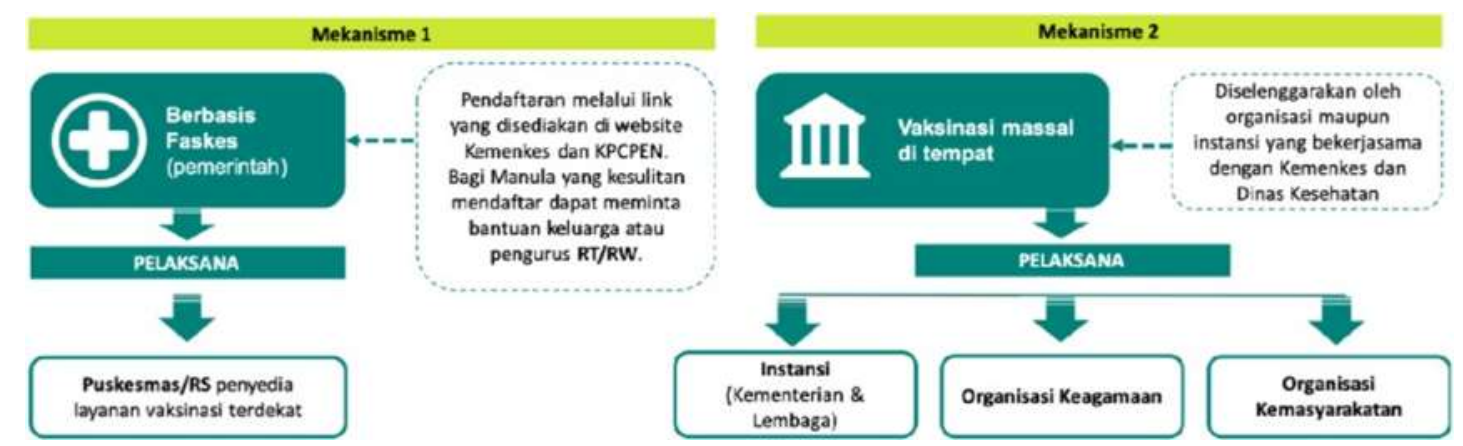

Source: https://www.kemkes.go.id/article/view/21022000004/Mekanisme-Pendaftaran- Vaksinasi-COVID19-pada-Lansia.html

Figure 4. Vaccination Registration Mechanism for the Community of the Elderly (60 Years and Over)

Elderly patients tend to experience multi-system organ dysfunction (Liu et al., 2020). As we get older, it is known that there are disturbances in the components of the immune system, both natural and adaptive, so that in the elderly there is a continuous production of inflammatory mediators and cytokines called "inflammation" or mild systemic chronic inflammation that occurs with physiological aging. TLR (Toll-Like Receptor) which assists APC (Antigen Presenting Cell) and PAMP (Pathogen Associated Molecular Patterns) to recognize the bacterial strategy, found to be imbalanced in the elderly resulting in an inappropriate immune response. Excessive immune system is able to explain the more involvement of hypertension in SARS-CoV2 infection that the TLR4 expression found in elderly people is higher in hypertensive conditions with decreased $\mathrm{T}$ cell function (Perrotta et al., 2020).

Pulmonary infection causes an increased burden on the work of the heart. In addition, the infection can cause high blood sugar levels resulting in difficulty in infection control. The presence of multi-system disease in elderly people causes complex disease conditions because these conditions can influence one another (Liu et al., 2020). 
The implementation of the COVID-19 vaccination has entered Phase 2 with the target group of seniors (aged 60 years and over) and public workers. Vaccination for this target group will start in Jakarta and provincial capitals for all provinces in Indonesia. However, in the initial phase, Java and Bali prioritized where more than 65 percent of national Covid-19 cases were recorded. Through public health facilities in both the clinic and government hospitals. Participants register by visiting the official website of the Ministry of Health, namely www.kemkes.go.id and Sehatnegeriku.kemkes.go.id, as well as the official website of the Committee for Handling COVID-19 and National Economic Recovery (KPCPEN) at www.covid19.go.id. On the three official sites, there will be a link or links that can be clicked by the elderly vaccination targets. In it there are a number of questions that must be filled in. In filling in the data, elderly participants can ask for help from other family members or through the head of the local RT or RW. After the participants fill in the data on the website, all participant data will go to the respective provincial health offices. Furthermore, the Health Office will determine the schedule, including the day, time, and location of the vaccination for the elderly community.

Through Mass vaccination programs by organizations and agencies, organizations or agencies can collaborate with the Ministry of Health or the Health Office to carry out mass vaccination for elderly participants. Organizations and agencies that have collaborated will determine the schedule, including the day, time, and location of vaccination for the elderly community.

Delays in vaccine delivery and immunization logistics may potentially lead to limited vaccines and immunization logistics at several administrative levels in provinces / districts / cities as well as health centers. The delay in vaccine distribution and logistics was caused by travel restrictions imposed by the government and various other public health-related efforts. At the service level of clinic and other health facilities officers are advised to monitor current stock levels, assess changes in consumption levels if immunization programs are continued or suspended, review cold chain capacity and modify vaccine planning, acceptance and distribution schedules as needed to avoid overloading the cold chain. . This is one of the most important activities in maintaining stock availability and preventing vaccine vacancies and other immunization logistics. The whole process of distribution of program vaccines down to the service level must maintain high quality of vaccines in order to be able to provide optimal immunity to the target.

In this situation, the difference between a low immunization rate and a positive attitude towards vaccination is striking. Previous findings seem to support the theory that there is a correlation between physicians' attitudes toward vaccination and the likelihood of patients being vaccinated. This study also refers to the dependence of patients on general practitioner recommendations for vaccination (Paterson et al., 2016). Therefore, it can be assumed that future strategies to increase vaccination coverage target not only patients but also their general practitioners.

The risk of infection with COVID-19 may be higher in chronic heart failure patients because of advancing age and the presence of several comorbidities. In heart failure patients with suspected COVID19, routine clinical assessment, temperature measurement with non-contact devices, ECG (arrhythmia, myocardial ischemia, myocarditis), chest Xray (cardiomegaly, pneumonia COVID-19) and laboratory findings (increased sedimentation rate, fibrinogen, protein $\mathrm{C}$ reactive, and lymphocytopenia) can provide diagnostic clues. Transthoracic echocardiography and chest CT scan may be used for further assessment. Particular attention should be paid to preventing transmission of the virus to health care providers or contamination of equipment. Patients with chronic heart failure should follow protective measures to prevent infection. Stable heart failure patients 
who are able to move (without a cardiac emergency) should reduce the visitation to hospital. Medical therapy recommended according to guidelines (including beta-blockers, ACEIs, ARBs and mineralocorticoid receptor antagonists) should be continued in patients with chronic heart failure, regardless of the presence or absence of COVID-19 infection. Telemedicine should be considered wherever possible to provide medical advice and follow-up of stable heart failure patients (PPDI et al., 2020).

In line with the progress of the COVID-19 vaccination program for health workers and various suggestions that emerged from conditions in the field, the Indonesian Internal Medicine Specialist Association (PAPDI) prepared a revised recommendation for the provision of COVID-19 (Coronavac) vaccination. This recommendation is prepared by considering several things: 1) Efforts to achieve herd immunity in the Indonesian population to cut off the transmission of COVID-1-9 so that a broad vaccination coverage is required; 2) Study of the Food and Drug Supervisory Agency (BPOM) on matters that are contraindicated and Precaution Coronavac; 3) Agreement from experts regarding the safety and benefits of vaccination against COVID-19; 4) Coronavac Emergency Use Authorization (EUA) permit for use over 59 years of age; 5) The fact that as of February 8, 2021, nearly 1 million people have been vaccinated against Coronavac and no significant AEFIs have been found (PPADI, 2021). PAPDI recommendations for individuals aged $>59$ years, vaccination eligibility is determined by the frailty condition of the individual obtained from the RAPUH questionnaire. If the value is above 2, then the individual is not suitable for coronavac vaccination.

The fragile questionnaire

1. R (Resistance)

With yourself or without the aid of a tool, do you have difficulty climbing 10 steps and without resting in between? (score $1=$ yes, $0=$ no)

2. A (Activity)

How often in 4 weeks did anyone feel calm

$1=$ all the time

$2=$ most of the time

$3=$ sometimes

$4=$ rarely

(if the answer is 1 or 2 , score $=1$ and other scores $=0$ )

3. P ((Penyakit)Disease more than 4$)$

Participants were asked if the doctor had ever told you about your disease (11 major diseases: hypertension, diabetes, cancer (other than minor skin cancer), chronic lung disease, heart attack, congestive heart failure, chest pain, asthma, joint pain, stroke and other diseases. kidney?) if the answer is the total number of diseases the score is $0-4$ diseases $=0$, and 5-11 diseases $=1$

4. Effort to walk / Ambulatory

On your own and without assistance, are you having trouble walking the roughly 100 to 200 meters? Score yes $=1$, and no $=0$

5. Loss of weight

How much do you weigh by wearing clothes without legs at this time

One year ago, how much did you weigh barefoot?

Information for Calculation of Weight in Percent: (Weight 1 Year Ago - Current Weight) / Weight 1 Than Previous X 100\%

If the result is $>5 \%$ (5\% weight loss), the score is 1 and $<5 \%$ the score $=0$

Interpretation: score 1-2: Pre-Frail (Pre-Fragile). Score $>2$ : Frail (Fragile / Vulnerable) 
The basic principle of efforts to tackle COVID-19 rests on the discovery of suspect / probable (find) cases, which are followed by efforts to isolate (isolate) and laboratory tests (tests). When the RT-PCR test result is positive and the patient is declared a confirmed case, then the next action is to administer therapy according to the protocol. Contact tracing (trace) must be carried out as soon as a suspect / probable case is found. Close contacts will be quarantined for 14 days. If after 14 days of quarantine there are no symptoms, then monitoring can be stopped. However, if during monitoring, close contact symptoms appear, it should be immediately isolated and checked for swabs (RT-PCR).

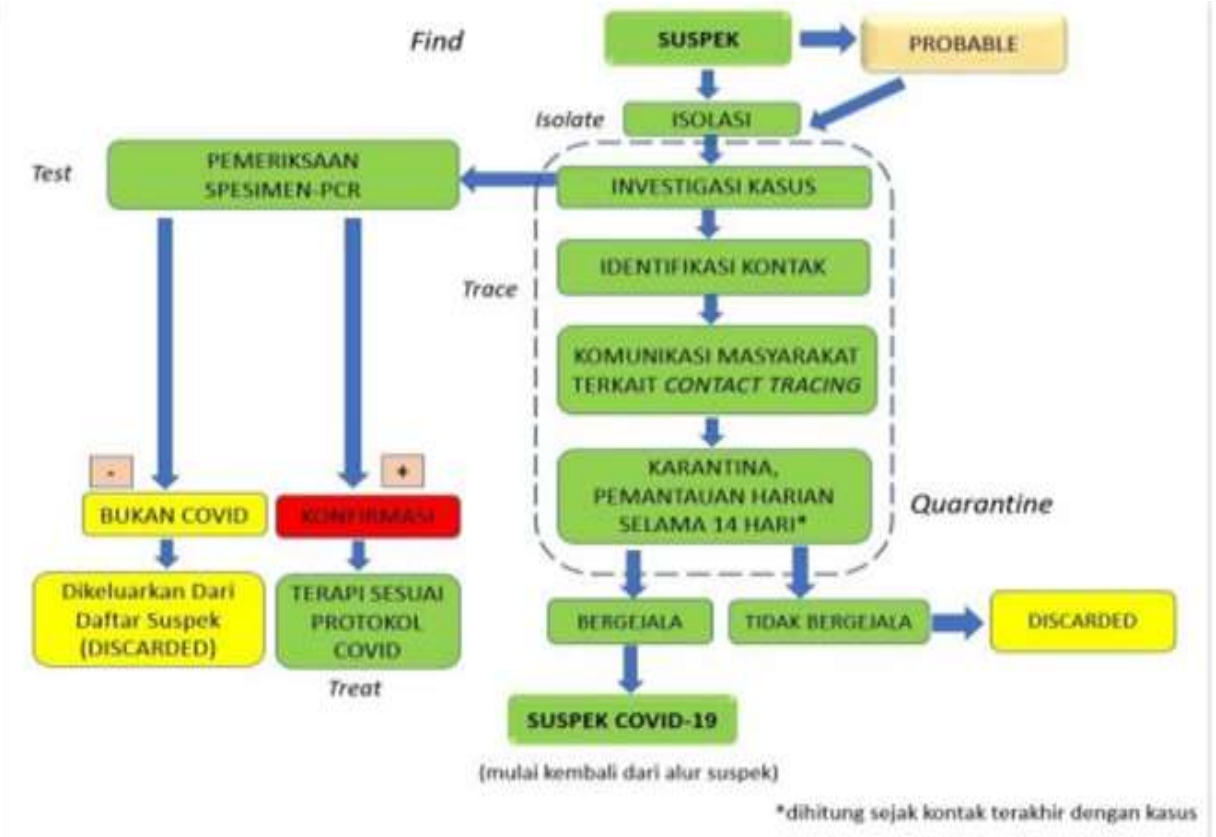

Source: (RI., 2020)

Figure 5. Flow of Public Health Management

Public health management is a series of public health activities carried out on cases. These activities include quarantine / isolation, monitoring, specimen examination, epidemiological investigations, and risk communication and community empowerment. The discussion regarding each activity is discussed in a separate section. Quarantine is the process of reducing the risk of transmission and early identification of COVID-19 through efforts to separate individuals who are healthy or do not have COVID-19 symptoms but have a history of contact with COVID-19 confirmed patients or have a history of traveling to areas where local transmission has occurred. Isolation is the process of reducing the risk of transmission through efforts to separate sick individuals who are either laboratory confirmed or have symptoms of COVID-19 from the wider community (RI., 2020).

\section{Conclusion}

Aging have good affects both the innate immune system and the acquired immune system through several mechanisms including telomere shortening, genetic factors and hormonal changes. Vaccination is a preventive strategy to increase the immunity of the elderly. Although the immune response is greatly reduced due to the aging process, the right adjuvant formulation can increase the effectiveness of the vaccine. Knowledge of the adjuvant mechanism to increase vaccine effectiveness is needed to develop a stronger vaccine response in elderly individuals. 


\section{References}

Amanat, F., \& Krammer, F. (2020). SARS-CoV-2 vaccines: status report. Immunity, 52(4), 583-589.

Azwar, M. K., Setiati, S., Rizka, A., Fitriana, I., Saldi, S. R. F., \& Safitri, E. D. (2020). Clinical Profile of Elderly Patients with COVID-19 hospitalised in Indonesia's National General Hospital. Acta Medica Indonesiana, 52(3), 199.

Bell, H. T., Granas, A. G., Enmarker, I., Omli, R., \& Steinsbekk, A. (2017). Nurses' and pharmacists' learning experiences from participating in interprofessional medication reviews for elderly in primary health care-a qualitative study. BMC Family Practice, $18(1), 1-9$.

Callaway, E. (2020). The race for coronavirus vaccines: a graphical guide. Nature, $580(7805), 576$.

Chen, W. H., Kozlovsky, B. F., Effros, R. B., Grubeck-Loebenstein, B., Edelman, R., \& Sztein, M. B. (2009). Vaccination in the elderly: an immunological perspective. Trends in Immunology, 30(7), 351-359.

Corsini, E., Vismara, L., Lucchi, L., Viviani, B., Govoni, S., Galli, C. L., Marinovich, M., \& Racchi, M. (2006). High interleukin-10 production is associated with low antibody response to influenza vaccination in the elderly. Journal of Leukocyte Biology, 80(2), 376-382.

COVID, G. P. (2020). 19. Peta Sebaran. Gugus Tugas Percepatan Penanganan COVID

19. Covid19. Go. Id.

Dey, A. B., Chatterjee, P., \& Das, P. C. (2012). Immune status in the elderly. Medicine Update.

Fagundes, C. P., Gillie, B. L., Derry, H. M., Bennett, J. M., \& Kiecolt-Glaser, J. K. (2012). Resilience and immune function in older adults. Annual Review of Gerontology and Geriatrics, 32(1), 29-47.

Giurgea, L. T., Han, A., \& Memoli, M. J. (2020). Universal coronavirus vaccines: the time to start is now. Npj Vaccines, 5(1), 1-3.

Glaser, R., Sheridan, J., Malarkey, W. B., MacCallum, R. C., \& Kiecolt-Glaser, J. K. (2000). Chronic stress modulates the immune response to a pneumococcal pneumonia vaccine. Psychosomatic Medicine, 62(6), 804-807.

Greenwood, B. (2014). The contribution of vaccination to global health: past, present and future. Philosophical Transactions of the Royal Society B: Biological Sciences, 369(1645), 20130433.

Güçyetmez, et al. (2020). Implications behind the Covid 19: A Profound Structural Change Out Of Catastrophy?. Britain International of Humanities and Social Sciences (BIoHS) Journal, 690-697.

Hoffmann, M., Kleine-Weber, H., Krüger, N., Mueller, M. A., Drosten, C., \& Pöhlmann, S. (2020). The novel coronavirus 2019 (2019-nCoV) uses the SARS- coronavirus receptor ACE2 and the cellular protease TMPRSS2 for entry into target cells. BioRxiv.

Indonesia, P. R. (2021). Petunjuk Teknis Pelaksanaan Vaksinasi Dalam Rangka Penanggulangan Pandemi Corona Virus Disease 2019 (Covid-19). Keputusan Direktur Jenderal Pencegahan Dan Pengendalian Penyakit Nomor Hk.02.02/4/ 4'13/2021.

Kaslow, D. C. (2020). Certainty of success: three critical parameters in coronavirus vaccine development. Npj Vaccines, 5(1), 1-7. 
Kiecolt-Glaser, J. K., Preacher, K. J., MacCallum, R. C., Atkinson, C., Malarkey, W. B., \& Glaser, R. (2003). Chronic stress and age-related increases in the proinflammatory cytokine IL-6. Proceedings of the National Academy of Sciences, 100(15), 90909095.

Li, Q., Guan, X., Wu, P., Wang, X., Zhou, L., Tong, Y., Ren, R., Leung, K. S. M., Lau,

E. H. Y., \& Wong, J. Y. (2020). Early transmission dynamics in Wuhan, China, of novel coronavirus-infected pneumonia. New England Journal of Medicine.

Li, T., Zhang, Y., Gong, C., Wang, J., Liu, B., Shi, L., \& Duan, J. (2020). Prevalence of malnutrition and analysis of related factors in elderly patients with COVID-19 in Wuhan, China. European Journal of Clinical Nutrition, 74(6), 871-875.

Liu, K., Chen, Y., Lin, R., \& Han, K. (2020). Clinical features of COVID-19 in elderly patients: A comparison with young and middle-aged patients. Journal of Infection, 80(6), e14-e18.

Lu, R., Zhao, X., Li, J., Niu, P., Yang, B., Wu, H., Wang, W., Song, H., Huang, B., \& Zhu, N. (2020). Genomic characterisation and epidemiology of 2019 novel coronavirus: implications for virus origins and receptor binding. The Lancet, 395(10224), 565574.

Mergenthal, K., Beyer, M., Gerlach, F. M., \& Guethlin, C. (2016). Sharing responsibilities within the general practice team-a cross-sectional study of task delegation in Germany. PloS One, 11(6), e0157248.

Morens, D. M., \& Taubenberger, J. K. (2019). Making universal influenza vaccines: lessons from the 1918 pandemic. The Journal of Infectious Diseases.

Ningrum, et al. (2020). The Potential of Poverty in the City of Palangka Raya: Study SMIs Affected Pandemic Covid 19. Budapest International Research and Critics InstituteJournal (BIRCI-Journal), 1626-1634.

Onder, G., Rezza, G., \& Brusaferro, S. (2020). Case-fatality rate and characteristics of patients dying in relation to COVID-19 in Italy. Jama, 323(18), 1775-1776.

Ongrádi, J., \& Kövesdi, V. (2010). Factors that may impact on immunosenescence: an appraisal. Immunity \& Ageing, 7(1), 1-14.

Paterson, P., Meurice, F., Stanberry, L. R., Glismann, S., Rosenthal, S. L., \& Larson, H.

J. (2016). Vaccine hesitancy and healthcare providers. Vaccine, 34(52), 6700- 6706.

Perrotta, F., Corbi, G., Mazzeo, G., Boccia, M., Aronne, L., D’Agnano, V., Komici, K., Mazzarella, G., Parrella, R., \& Bianco, A. (2020). COVID-19 and the elderly: insights into pathogenesis and clinical decision-making. Aging Clinical and Experimental Research, 1-10.

PPADI. (2021). Rekomendasi PAPDI tentang Pemberian Vaksinasi covlD-19 (coronavac) pada Pasien dengan Penyakit Penfdrta/ Komorbid (Revisi 9 Februari 2021). PENGURUS BESAR PERHIMPUNAN DOKTER SPESIALIS PENYAKIT DALAM INDONESIA.

PPDI, PERKI, PAPDI, PERDATIN, \& IDAI. (2020). PEDOMAN TATALAKSANA

COVID-19 (E. Burhan, A. D. Susanto, F. Isbaniah, S. A. Nasution, Eka, Ginanjar,

C. W. Pitoyo, A. Susilo, I. Firdaus, A. Santoso, D. A. Juzar, S. K. Arif, N. G. . L. Wulung, \& F. Muc (eds.); 3rd ed.).

RI., K. K. (2020). Pedoman Pencegahan Pengendalia Coronavirus Disease (COVID- 19) (S. K. dr. Listiana Aziza, S. Adistikah Aqmarina, \& S. Maulidiah Ihsan (eds.); 13 Juli 20).

Schuchat, A. (2011). Human vaccines and their importance to public health. Procedia in Vaccinology, 5, 120-126. 
Shang, W., Yang, Y., Rao, Y., \& Rao, X. (2020). The outbreak of SARS-CoV-2 pneumonia calls for viral vaccines. Npj Vaccines, 5(1), 1-3.

Sihombing, E. H., Nasib. (2020). The Decision of Choosing Course in the Era of Covid 19 through the Telemarketing Program, Personal Selling and College Image. Budapest International Research and Critics Institute-Journal (BIRCI-Journal), 2843-2850.

Tay, M. Z., Poh, C. M., Rénia, L., MacAry, P. A., \& Ng, L. F. P. (2020). The trinity of COVID-19: immunity, inflammation and intervention. Nature Reviews Immunology, 20(6), 363-374.

Team, C. D. C. C.-19 R., Team, C. D. C. C.-19 R., Team, C. D. C. C.-19 R., Bialek, S.,

Boundy, E., Bowen, V., Chow, N., Cohn, A., Dowling, N., \& Ellington, S. (2020). Severe outcomes among patients with coronavirus disease 2019 (COVID-19) - United States, February 12-March 16, 2020. Morbidity and Mortality Weekly Report, 69(12), 343-346.

Weltermann, B. M., Markic, M., Thielmann, A., Gesenhues, S., \& Hermann, M. (2014). Vaccination management and vaccination errors: a representative online-survey among primary care physicians. PloS One, 9(8), e105119.

Zhou, P., Yang, X.-L., Wang, X.-G., Hu, B., Zhang, L., Zhang, W., Si, H.-R., Zhu, Y., Li, B., \& Huang, C.-L. (2020). A pneumonia outbreak associated with a new coronavirus of probable bat origin. Nature, 579(7798), 270-273. 